\title{
Influence of Chemical and Mechanical Polishing on Water Sorption and Solubility of Denture Base Acrylic Resins
}

\author{
Juliana Saab RAHAL ${ }^{1}$ \\ Marcelo Ferraz MESQUITA ${ }^{2}$ \\ Guilherme Elias Pessanha HENRIQUES ${ }^{2}$ \\ Mauro Antonio Arruda NÓBILO ${ }^{2}$ \\ ${ }^{1}$ Department of Prosthodontics, Paranaense University (UNIPAR), Umuarama, PR, Brazil \\ ${ }^{2}$ Department of Prosthodontics and Periodontology, School of Dentistry of Piracicaba, \\ State University of Campinas - UNICAMP, Piracicaba, SP, Brazil
}

\begin{abstract}
Influence of polishing methods on water sorption and solubility of denture base acrylic resins was studied. Eighty samples were divided into groups: Clássico (CL), and QC 20 (QC) - hot water bath cured; Acron MC (AC), and Onda Cryl (ON) - microwave cured; and submitted to mechanical polishing (MP) - pumice slurry, chalk powder, soft brush and felt cone in a bench vise; or chemical polishing (CP) - heated monomer fluid in a chemical polisher. The first desiccation process was followed by storage in distilled water at $37 \pm 1{ }^{\circ} \mathrm{C}$ for $1 \mathrm{~h}, 1$ day, 1, 2, 3 and 4 weeks. Concluding each period, water sorption was measured. After the fourth week, a second desiccation process was done to calculate solubility. Data were submitted to analysis of variance, followed by Tukey test ( $\mathrm{p} \leq 0.05)$. Means of water sorption (\%) and solubility (\%), respectively, were: CL-MP: 1.92 and 0.02; CL-CP: 1.98 and 0.52; QC-MP: 2.31 and -0.05; QC-CP: 2.32 and 0.25; AC-MP: 2.45 and -0.07; AC-CP: 2.43 and 0.41; ON-MP: 2.32 and -0.06; ON-CP: 2.34 and 0.27. Mechanical polishing promoted significantly lower solubility of acrylic resins; initially, water sorption values were higher for chemically polished samples, however, after 4 weeks all groups were similar.
\end{abstract}

Key Words: acrylic resin, water sorption, solubility, chemical polishing, mechanical polishing.

\section{INTRODUCTION}

Acrylic resin is the most employed material in partial removable or complete denture bases. This material began to be used in the 1930s in substitution of vulcanite. Polymethylmethacrylate is the most used acrylic resin and is characterized as being strong, having satisfactory optical properties, copying oral tissue appearance, showing low water sorption and solubility to oral tissues, and having good dimensional stability (1).

There are conventional and alternative methods to work with the acrylic resin. One alternative method is the use of microwave energy for curing. This method has been studied since 1968, when Nishii (2) published the first report about microwave curing.
Another alternative method is the use of chemical polishing instead of mechanical polishing first reported by Gotusso in 1969 (3). This technique employs the immersion of a denture in heated monomer fluid and eliminates the use of a bench vise in the final process of polishing dentures. It is indicated not only to facilitate the process of polishing but also in cases in which it is very difficult or impossible to achieve mechanical polishing, i.e. the inner surface of the open bulb of the buccal flange obturator (4). Biocompatibility of this technique was studied by Nagem Filho et al. (5); however, there are few reports in the literature about this polishing technique and a more recent chemical polishing technique has not yet been studied.

Research of alternative techniques is essential to prove their efficacy and viability, especially if associ-

Correspondence: Dr. Marcelo Ferraz Mesquita, Departamento de Prótese e Periodontia, Faculdade de Odontologia de Piracicaba, UNICAMP, Avenida Limeira, 901, Caixa Postal 52, Bairro Areião, 13414-018 Piracicaba, SP, Brasil. Tel: +55-19-430-5350. Fax: +55-19-430-5218. e-mail: mesquita@fop.unicamp.br 
ated with other techniques. It is important to determine the effects these techniques may cause to acrylic resin and its properties. One property is water sorption. The water absorbed into the material acts as a plasticizer and decreases the mechanical properties such as hardness, transverse strength and fatigue limit (6). Water sorption can also influence dimensional stability (7-9). Solubility is also an important property because it represents the mass of soluble materials (residual monomer, plasticizing and initiating) from the polymers (10).

Due to the importance of these properties in the clinical performance of a denture, this study has the objective of analyzing the influence of chemical and mechanical polishing on water sorption and solubility of different acrylic resins.

\section{MATERIAL AND METHODS}

Specimen discs, $50 \pm 1 \mathrm{~mm}$ in diameter and 0.5 $\pm 0.05 \mathrm{~mm}$ thick, were prepared in accordance with ADA Specification No. 12 (11) for denture base polymers. Acrylic resins were mixed and manipulated according to manufacturer instructions and the following cycles were carried out: 1) Acron MC (GC America, Alsip, IL) - $3 \mathrm{~min} / 500 \mathrm{~W}$ by microwave energy; 2) Onda Cryl (Clássico Artigos Odontológicos, São Paulo, Brazil) $-3 \mathrm{~min} / 40 \%$ of maximum potency, $4 \mathrm{~min} /$ pause, and $3 \mathrm{~min} / 60 \%$ of maximum potency by microwave energy; 3) Clássico (Clássico Artigos Odontológicos, São Paulo, Brazil) $-9 \mathrm{~h} / 74 \pm 1{ }^{\circ} \mathrm{C}$ by hot water bath; 4) QC 20 (Dentsply De Trey, Rio de Janeiro, Brazil) $-20 \mathrm{~min} / 100^{\circ} \mathrm{C}$ by boiling water bath. Twenty specimens of each acrylic resin were constructed. The specimens were reduced by machine grinding (Arotec APL 04, São Paulo, Brazil) procedures employing abrasive papers in successive grits of 320, 400 and 600. Each acrylic resin group was subdivided and half received mechanical polishing and other half chemical polishing. Mechanical polishing was performed in a bench vise using a rotating soft brush with pumice slurry followed by a rotating felt cone with chalk powder. Chemical polishing was conducted in a chemical polisher (PQ 9000, Termotron, Piracicaba, SP, Brazil) having heated monomer fluid (Poli-Quim) at approximately $75^{\circ} \mathrm{C}$. Specimens were immersed in this fluid for $10 \mathrm{~s}$ using tweezers, removed to room temperature for $15 \mathrm{~s}$ and washed in running water for $1 \mathrm{~min}$ to eliminate excess fluid.
All specimens were dried in a desiccator containing thoroughly dry silica gel at $37 \pm 2^{\circ} \mathrm{C}$ for $24 \mathrm{~h}$, removed to room temperature for $1 \mathrm{~h}$, then weighed in an analytical balance of $0.1 \mathrm{mg}$ precision (AP-250D, Ohaus Corporation, Florhan Park, Switzerland). This cycle was repeated until the weight loss of each specimen was no more than $0.5 \mathrm{mg}$ in any $24-\mathrm{h}$ period. The specimens were immersed in distilled water at $37 \pm 2^{\circ} \mathrm{C}$ for $1 \mathrm{~h}, 1$ day, 1, 2, 3, and 4 weeks. After each period the specimens were removed from the water with tweezers, wiped with a clean, dry hand towel until free from visible moisture, waved in the air for $15 \mathrm{~s}$ and weighed 1 min after removal from the water. At the end of 4 weeks, the specimens were again submitted to a desiccation process.

The final values of water sorption and solubility were obtained using the following formulas:

Water sorption $\left(\mathrm{mg} / \mathrm{cm}^{2}\right)=$

mass after immersion (mg) - conditioned mass (mg)

surface area $\left(\mathrm{cm}^{2}\right)$

Solubility $\left(\mathrm{mg} / \mathrm{cm}^{2}\right)=$

conditioned mass $(\mathrm{mg})$ - reconditioned mass $(\mathrm{mg})$

surface area $\left(\mathrm{cm}^{2}\right)$

The mean values of water sorption test were submitted to analysis of variance followed by Tukey test, at $5 \%$ probability.

\section{RESULTS}

\section{Water Sorption}

Resins behaved similarly within each polishing type (Table 1). When considering resins independent of polishing type, Clássico resin presented the highest mean water sorption at $1 \mathrm{~h}$, not differing statistically only from QC 20 resin, while Acron MC resin presented the lowest mean. Independent of resins, mechanical polishing presented the lowest mean, being significantly different from chemical polishing (Tukey test).

For 1-day or more, analysis indicated that triple interaction (resin x polishing $\mathrm{x}$ time) was significant. Thus, detailed analysis of one factor inside the combination of levels of the two other factors is presented in Table 2. Significant differences occurred between the 
two polishing techniques only within Acron MC resin and from the second week on at which mechanical polishing presented the highest means. In comparison of resins, it was verified that Clássico resin presented the lowest numerical average in all situations (combination of polishing and time levels). It was clearly noted that Acron MC resin showed the highest numerical values of water sorption with mechanical polishing at all periods, while QC 20 resin showed the highest numerical means of water sorption at all periods with chemical polishing. Also at 2, 3 and 4 weeks the mechanical polishing had higher means than chemical polishing. The means of Acron MC and QC 20 did not differ significantly (Tukey test) in any situation.
Table 1. Mean values $\left(\mathrm{mg} / \mathrm{cm}^{2}\right)$ of water sorption at $1 \mathrm{~h}$ for resins, types of polishing, and resins inside the variable polishing.

\begin{tabular}{llll}
\hline Resins & \multicolumn{2}{c}{ Polishing } & \multirow{2}{*}{ Mean/Resin } \\
\cline { 2 - 3 } & Mechanical & Chemical & \\
\hline Clássico & 0.3727 a A & 0.3888 a A & $0.3808 \mathrm{~A}$ \\
QC 20 & 0.3645 a A & 0.3729 a A & $0.3687 \mathrm{AB}$ \\
Acron MC & 0.2737 a B & 0.2885 a B & $0.2811 \mathrm{C}$ \\
Onda Cryl & 0.3521 a A & 0.3654 a A & $0.3587 \mathrm{~B}$ \\
Mean/Polishing & $0.3407 \mathrm{~b}$ & $0.3539 \mathrm{a}$ & \\
\hline
\end{tabular}

Means followed by the same small letter in lines, and capital letter in columns were statistically similar (Tukey test at 5\% probability).

\section{Solubility}

The results of the Tukey test confirmed analysis of variance showing that resin solubility differed statistically for the two types of polishing. Clássico resin presented the highest numerical mean for solubility for both polishing techniques, not differing only from Acron MC resin in chemical polishing. The lowest numerical means for solubility were obtained by Acron $\mathrm{MC}$ resin with mechanical polishing and by QC 20 resin with chemical polishing, which differed from Clássico resin in both polishing techniques (Table 3 ).

Table 4 presents percent of water sorption and solubility after 4 weeks of storage. At the end of this period only the Clássico resin differed from the others in terms of water sorption. Values were significantly lower after both polishing techniques. Water sorption values were similar for the other resins after 4 weeks storage regardless of polishing technique.

Concerning solubility, of all mechanically polished resins, Clássico had the highest percentage, differing significantly from the others. Of those chemically polished, Clássico and Acron MC presented the highest values and were statistically similar. Clássico differed statistically from the other resins, whereas
Table 3. Mean values $\left(\mathrm{mg} / \mathrm{cm}^{2}\right)$ of solubility obtained for resins inside the variable polishing.

\begin{tabular}{lcc}
\hline Resins & \multicolumn{2}{c}{ Solubility } \\
\cline { 2 - 3 } & Mechanical Polishing & Chemical Polishing \\
\hline Clássico & $0.0071 \mathrm{~A}$ & $0.2450 \mathrm{~A}$ \\
QC 20 & $-0.0221 \mathrm{~B}$ & $0.1215 \mathrm{~B}$ \\
Acron MC & $-0.0326 \mathrm{~B}$ & $0.1848 \mathrm{AB}$ \\
Onda Cryl & $-0.0243 \mathrm{~B}$ & $0.1227 \mathrm{~B}$ \\
\hline
\end{tabular}

Means followed by the same capital letter in columns were statistically similar (Tukey test at 5\% probability). 
Acron MC was statistically similar to the others. On the other hand, solubility values of the resin types differed statistically when polishing techniques were compared. Mechanical polishing values were always lower than those of chemical polishing.

\section{DISCUSSION}

Water Sorption

The influence of resin type employed, polishing type, but not of the interaction resin x polishing on the results was evaluated for water sorption for 1-h storage. Evaluating polishing types, independent of resins, groups mechanically polished showed lower sorption than those chemically polished, differing statistically between themselves (Table 1). Gotusso et al. (3) affirmed that chemical polishing reduced water sorption of acrylic resins. It is important to remember that in that study, the comparison was conducted between samples chemically polished and no polishing, probably with more irregular surfaces. There is a parameter named hysteresis of contact angle formed between the water drop and the resin (the difference between the initial contact angle and the later one); this parameter is proper to analyze the relation acrylic resin surface $\mathrm{x}$ water. Monsénégo et al. (12) showed that the contact angle hysteresis on surfaces submitted to abrasion (rougher) is lower than on polished surfaces, considering that lower angles characterize more hydrophilic surfaces. Although water sorption always occurs in acrylic resins, independent of surface conditions, the sorption ratio is accelerated in rougher materials, i.e.,

Table 4. Water sorption (\%) and solubility (\%) values obtained by resins mechanically (MP) and chemically polished (CP) after 4 weeks of storage.

\begin{tabular}{lccccc}
\hline Resins & \multicolumn{2}{c}{ Water Sorption } & & \multicolumn{2}{c}{ Solubility } \\
\cline { 2 - 3 } \cline { 6 - 7 } & MP & CP & & MP & CP \\
\hline Clássico & 1.92 a A & 1.98 a A & & 0.02 a A & 0.52 b A \\
QC 20 & 2.31 a B & 2.32 a B & & -0.05 a B & 0.25 b B \\
Acron MC & 2.45 a B & 2.43 a B & & -0.07 a B & 0.41 b AB \\
Onda Cryl & 2.32 a B & 2.34 a B & & -0.06 a B & 0.27 b B \\
\hline
\end{tabular}

Means followed by the same small letter in lines and capital letter in columns were statistically similar (Tukey test at $5 \%$ probability). the water entrance in porous surfaces present in acrylic resin submitted to abrasion increases its hydrophilic characteristic $(13,14)$.

Considering only water sorption and no polishing of the resins, the mean water sorption was the highest for Clássico resin and lowest for Acron MC (Table 1). Miettinen and Vallittu (10) reported that acrylate type has influence on resin water sorption degree. This is due to the chemical structure formed after curing. Clássico resin is formed through the interaction of methyl methacrylate molecules that form a structure with simple polymeric chains of linear configuration, with a larger volume of interstitial matrix (15), the area of water molecule penetration. However, Acron MC resin possesses crosslink agents in its composition that changes its reaction, formatting more tight, complex and interlaced chains, and also longer polymeric chains by the presence of co-polymers, leading to a less voluminous interstitial matrix. It does not give the opportunity for water molecules to enter in quantity and velocity as great as Clássico resin. This is in agreement with reports of Takahashi et al. (16), who cited that the quantity of water sorption depends on the material type and the thickness of the material, and highly crosslinked materials generally exhibit lower water sorption compared to non-crosslinked materials.

It was noted that results of 1 day, 1, 2, 3 and 4 weeks of storage were inverse to those occurring after 1 $\mathrm{h}$ of water storage; even though they were opposite, the justification is the same. Water sorption, i.e. water molecule diffusion among the resin polymeric chains will occur by any means, what changes is the time necessary for this, that is related to the resin's chemical structure. Thus, Clássico resin that showed high water sorption in the first hour, continued allowing the entrance of water, but more slowly and in lower quantity, because the quantity absorbed initially was almost enough to reach the maximum limit of sorption or to reach equilibrium. Szabó et al. (17) reported that, in thin specimens of approximately $1 \mathrm{~mm}$ diameter, the water uptake was independent of storage time in water after $24 \mathrm{~h}$ and also independent of the type of denture base polymer. Acron MC resin showed inverse behavior, justly because the arrangement of its polymeric chains makes the diffusion of water molecules difficult, thus there is only penetration of the resin's lacuna with a longer storage period.

Other observed behavior is that chemically pol- 
ished specimens of all resins showed decreasing sorption degree from the first day until the fourth storage week, while those mechanically polished showed constant behavior in this period. This occurred because the larger initial contact with water molecules, promoted by chemical polishing, caused these specimens to absorb more water initially, with sorption decreasing gradually. The specimens mechanically polished showed a slower and constant sorption, without influence of time. The suggestion is that probably the acrylic resin specimens had reached water sorption equilibrium or saturation in the period of only one day and then remained constant.

\section{Solubility}

Analyzing only the polishing factor, independent of resin types, higher solubility degree was observed in chemical polishing than in mechanical polishing (Table 3) because solubility is directly related to residual monomer releasing, which is higher in chemically polished resins.

The present results showed higher solubility values for Clássico resin, in both polishing groups, differing statistically from others, except from chemically polished Acron MC resin. The fact of having simpler structure of polymeric chains, joined by more fragile unions, increases the susceptibility of breaking these unions, with fluids entering and releasing nonreacted substances. High water sorption index of this resin in the first storage period corroborates this fact, which coincides with the residual monomer releasing apex (18). Truong and Thomasz (19) observed residual monomer concentration slightly higher in hot water bath cured acrylic resins compared with those cured by microwave energy. Crosslink agents also exert influence on these results. Clássico resin does not have these agents and their presence in the acrylic resin composition leads to decreasing solubility, with this tendency becoming higher with the increase of its concentrations $(6,20)$. In research by Sheridan et al. in 1997 (18), Acron MC resin also behaved in a different manner than a conventional heat cured acrylic resin, when evaluated for toxicity, a factor directly related to residual monomer release and other chemical substances compounding acrylic resins. They observed that Acron MC toxicity was higher only after $96 \mathrm{~h}$ of culture immersion, while another resin showed higher toxicity in the first hours, decreasing gradually. This behavior of Acron MC was a signal of its slow monomer releasing.

According to tests performed in this research, it can be inferred that chemical polishing increases water sorption in the first storage period compared to mechanical polishing. At the end of four weeks, for each acrylic resin type employed, the water sorption ratio was the same, independent of the polishing to which the resin was submitted. Concerning solubility, acrylic resins submitted to chemical polishing showed significantly higher values than those submitted to mechanical polishing.

\section{RESUMO}

Este estudo avaliou a influência dos métodos de polimento na absorção de água e solubilidade da resina acrílica para base de prótese. Foram confeccionadas 80 amostras, divididas nos seguintes grupos: Clássico (CL), e QC 20 (QC) - polimerização por banho de água aquecida; Acron MC (AC), e Onda Cryl (ON) - polimerização por microondas; e submetidas ao polimento mecânico (PM) - pasta de pedra pomes, branco de Espanha, escova macia e cone de feltro em torno de bancada; ou polimento químico (PQ) - monômero específico em polidora química. $\mathrm{O}$ primeiro processo de dessecação foi seguido de armazenagem em água destilada a $37 \pm 1^{\circ} \mathrm{C}$ por $1 \mathrm{~h}, 1$ dia, $1,2,3$ e 4 semanas. Ao término de cada período, foi realizada mensuração da absorção de água. Após a quarta semana, um segundo processo de dessecação foi realizado para o cálculo da solubilidade. Os resultados foram submetidos à análise de variância e teste de Tukey $(\mathrm{p} \leq 0,05)$. As médias de absorção de água (\%) e solubilidade (\%), respectivamente, foram: CL-PM: 1,92 e 0,02; CL-PQ: 1,98 e 0,52; QC-PM: 2,31 e -0,05; QC-PQ: 2,32 e 0,25; AC-PM: 2,45 e -0,07; AC-PQ: 2,43 e 0,41; ON-PM: 2,32 e -0,06; ON-PQ: 2,34 e 0,27 . O polimento mecânico promoveu menor solubilidade para as resinas acrílicas; inicialmente, os valores de absorção de água foram maiores para as amostras polidas quimicamente, entretanto, após 4 semanas todos os grupos apresentaram-se semelhantes entre si.

\section{ACKOWLEDGEMENTS}

We thank to FAPESP for financial support of this research (grant \#99/03344-3).

\section{REFERENCES}

1. Spencer HR, Gariaeff P. The present status of vulcanite versus plastics as a baseplate material. Contact Point 1949;27/28:263267.

2. Nishii M. Studies on the curing of denture base resins with microwave irradiation: with particular reference to heat-curing resins. J Osaka Dent Univ 1968;2:23-40.

3. Gotusso MJ. Tratamiento químico e superficial de las resinas 
acrílicas. Rev Asoc Odontol Argent 1969;57:359-361.

4. Aslan Y, Avci M. Monopoly coating on acrylic resin surfaces: a bacteriologic study. J Prosthet Dent 1990;63:478-481.

5. Nagem Filho H, Chiodi-Neto J, Araujo PA. Biocompatibility of acrylic resins implants in connective tissue. Estomatol Cult 1973;7:120-123

6. Arima T, Murata H, Hamada T. The effects of cross-linking agents on the water sorption and solubility characteristics of denture base resin. J Oral Rehabil 1996;23:476-480.

7. Barsby MJA. Denture base resin with low water absorption. J Dent 1992;20:240-244.

8. Cucci ALM, Vergani CE, Giampaolo ET, Afonso MCSF. Water sorption, solubility and bond strength of two autopolymerizing acrylic resins and one heat-polymerizing acrylic resin. J Prosthet Dent 1998;80:434-438.

9. Wong DMS, Cheng LYY, Chow TW, Clark RKF. Effect of processing method on the dimensional accuracy and water sorption of acrylic resin dentures. J Prosthet Dent 1999;81:300-304.

10. Miettinen VM, Vallittu PK. Water sorption and solubility of glass fiber-reinforced denture polymethyl methacrylate resin. J Prosthet Dent 1996;77:531-534.

11. American Dental Association. Revised American Dental Association Specification N. 12 for denture base polymers. J Am Dent Assoc 1975;90:451-458.

12. Monsénégo P, Baszkin A, Costa ML, Lejoyeux J. Complete denture retention. Part II: wettability studies on various acrylic resin denture base materials. J Prosthet Dent 1989;62:308-312.

13. Kilani BHZ, Retief DH, Guldag MV, Castleberry DJ, Fischer TE. Wettability of selected denture base materials. J Prosthet Dent 1984;52:288-291.

14. Monsénégo P. L'interface muco-prothéique en prothèse adjoinant caractérisation microscopique, physicochimique et microbiologique des poymères acryliques. [Thesis] Paris: University of Paris; 1987.

15. Anusavice KJ. Phillips: Materiais Dentários. 10th ed. Rio de Janeiro: Guanabara Koogan 1998.

16. Takahashi Y, Chai J, Kawaguchi M. Effect of water sorption on the resistance to plastic deformation of a denture base material relined with four different denture reline materials. Int $\mathrm{J}$ Prosthodont 1998;11:49-54.

17. Szabó G, Valderhaug J, Ruyter E. Some properties of a denture acrylic coating. Acta Odontol Scand 1985;43:249-256.

18. Sheridan PJ, Koka S, Ewoldsen NO, Lefebvre CA, Lavin MT. Cytotoxicity of denture base resins. Int J Prosthodont 1997;10:7377.

19. Truong VT, Thomasz FGV. Comparison of denture acrylic resins cured by boiling water and microwave energy. Aust Dent $\mathrm{J}$ 1988;33:201-204.

20. Harrison A, Huggett R, Jagger RC. The effect of a cross-linking agent on the abrasion resistance and impact strength of an acrylic resin denture base material. J Dent 1978;6:299-304.

Accepted April 7, 2003 